\title{
DALY indicator as an assessment tool for indoor air quality impact on human health
}

\author{
Monika Wysocka ${ }^{1, *}$ \\ ${ }^{1}$ Bialystok University of Technology, Faculty of Civil Engineering and Environmental Engineering, \\ Department of Heat Engineering, Wiejska 45E, 15-351 Białystok, Poland
}

\begin{abstract}
The quality of indoor environment is an extremely important issue, because people spend large parts of the day inside buildings. The quality of the indoor environment is largely dependent on the quality of indoor air. The parameters of the air we breathe affect our health and comfort of room use. Currently, when energy efficiency is a priority, it is difficult to maintain comfort and conditions appropriate for human health. The artificial environment in a room and related inadequate air quality cause many diseases, such as asthma, lung diseases, cardiovascular diseases, as well as poor well-being and reduced productivity. The Disability Adjusted Life Years (DALY) indicator means "loss of life corrected by disability" and is widely used by the World Health Organization to measure a disease burden on the population and identify the causes of a disease. The aim of the article is to present the structure of the DALY indicator and its suitability to assess the impact of indoor air quality on human health. The most frequent diseases caused by low quality of internal air were analysed based on statistical data. In addition, the possibilities of ventilation solutions have been presented, leading to the improvement of air quality in indoor environment.
\end{abstract}

\section{Introduction}

The quality of indoor environment is a very important issue, because users of rooms spend a significant part of the day inside buildings, not being aware of health and well-being implications. The quality of indoor environment is largely dependent on the quality of indoor air. Currently, when energy efficiency is a priority, it is difficult to maintain comfort and conditions appropriate for human health indoors. Due to the economic aspects and the emphasis on the largest possible energy savings, the issue of air quality is neglected. Striving to achieve the highest possible insulation of buildings results in limiting the natural exchange of air between the internal and external environment. Therefore, there is a need to design and install ventilation systems adapted to the needs of a given building and its users [1-3].

The air quality in buildings is considered with regards to health protection and comfort of room users It is shaped both by physical and chemical parameters, which make the interior microclimate - an ecosystem that allows the formation of favourable conditions for people.

To assess the microclimate quality, the following should be done [2, 4]:

- recognize and describe the source of financial issues,

* Corresponding author: m.wysocka@doktoranci.pb.edu.pl 
- analyse method of air exchange and movement, both inside and outside the building,

- examine ratio of permeability of partitions to the amount of impurities,

- determine mutual influence of impurities of physical and chemical nature, affecting the degree of their concentration.

- characterize mode and lifestyle of users of the investigated rooms.

People spend on average 80 to $90 \%$ of their time in closed rooms, while children, sick or elderly people spend up to $95 \%$, so they are even more exposed to the influence of harmful factors in the air $[4,5]$. Referring to the study of the Central Statistical Office, the following data can be quoted [4]:

$-62 \%$ of adults and $25 \%$ of children are chronically ill for at least one disease,

$-1 / 3$ of teenagers, $50 \%$ of people aged $30-39$ and the majority of older people are constantly ill,

- about $80 \%$ of deaths are caused by civilization diseases, i.e. arising as a result of poor quality of the surrounding environment.

As we live in a moderate climate zone, we spend most of our time indoors. Therefore, the indoor environment and its microclimate has the strongest effect on human well-being, health and productivity. $[4,6]$.

\section{Internal air pollution and diseases}

Nowadays, people spend most of their time indoors. Therefore, they are exposed to the harmful effects of airborne contaminants. The problem of air pollution is of increasing interest as the concentration of undesirable substances is constantly rising. This is caused by increased emissions from artificial materials and reduction of the ventilation flow due to energy saving strategies. Air pollution has a diversified genesis. The most common impurities occurring in rooms are characterized below (Table 1.) $[7,8]$.

Table 1. Sources and types of pollution in rooms.

\begin{tabular}{|c|c|c|}
\hline $\begin{array}{c}\text { Types of pollution } \\
\text { sources }\end{array}$ & Examples of sources & Type of pollution released \\
\hline Outside & atmospheric air & $\mathrm{SO}_{2}, \mathrm{NO}_{2}, \mathrm{NO}, \mathrm{O}_{3}$, hydrocarbons, dust \\
\hline \multirow{4}{*}{ Building materials } & concrete, stone & radon \\
\hline & chipboard, plywood & formaldehyde \\
\hline & insulating materials & glass fiber, thinners \\
\hline & glues, paints & organic solvents, mercury, chromium \\
\hline \multirow{3}{*}{ Room equipment } & exhaust devices & $\mathrm{CO}, \mathrm{NO}, \mathrm{NO}_{2}$ \\
\hline & furniture & organic solvents, dust \\
\hline & water and sewage installation & radon \\
\hline Human organism & metabolism products & $\mathrm{H}_{2} \mathrm{O}, \mathrm{CO}_{2}, \mathrm{NH}_{3}$, smell \\
\hline \multirow{3}{*}{ Human activity } & tobacco smoke & $\mathrm{CO}, \mathrm{NO}_{2}$, tar compounds \\
\hline & aerosols & hydrofluorocarbons, vinyl chloride \\
\hline & cleaning agents & $\mathrm{NH}_{3}$, fragrances, organic compounds \\
\hline
\end{tabular}

Source: [8].

Table 1 presents sources and types of pollution typical for enclosed spaces. They are related to everyday human functioning, metabolic changes occurring in the body, and materials used to construct buildings and surrounding objects. Indoor air has high concentration of harmful compounds and chemicals, so it is difficult to determine their exact amount and concentration. The influence of many of them on the human body is still 
unexamined. The most common pollutants that have the most significant impact on the deterioration of air quality include: carbon monoxide and dioxide, nitrogen oxides, ozone, volatile organic compounds, formaldehyde, radon, tobacco smoke, particulate matter, microorganisms $[6,8,9]$.

Table 2. The impact of air pollution on the human body.

\begin{tabular}{|l|l|}
\hline \multicolumn{1}{|c|}{$\begin{array}{c}\text { Types of pollution } \\
\text { sources }\end{array}$} & \multicolumn{1}{c|}{ Effects on the human body } \\
\hline Carbon dioxide $\left(\mathrm{CO}_{2}\right)$ & $\begin{array}{l}\text { fainting, headaches, rapid breathing and breathing difficulties, } \\
\text { blurred vision, increased pressure and faster heart rate }\end{array}$ \\
\hline Carbon monoxide $(\mathrm{CO})$ & $\begin{array}{l}\text { highly toxic, combining with haemoglobin causes permanent tissue } \\
\text { hypoxia, damage to the heart and nervous system, and eventually } \\
\text { death (lethal concentration is } 0.32 \% \text { (3200ppm) and exposure } \\
30 \text { minutes }\end{array}$ \\
\hline Nitrogen oxides $\left(\mathrm{NO}_{\mathrm{NO}}\right)$ & adverse effect on the respiratory system, hypoxia \\
\hline Ozone & $\begin{array}{l}\text { irritation of the respiratory tract, diseases and damage to the lungs } \\
\text { and bronchi }\end{array}$ \\
\hline $\begin{array}{l}\text { Volatile organic } \\
\text { compounds }(\mathrm{VOCs})\end{array}$ & carcinogenic \\
\hline Formaldehyde & irritation of mucous membranes, allergy, cough and tearing \\
\hline Radon & carcinogenic \\
\hline Tobacco smoke & asthma, bronchial and lung cancer \\
\hline PM10, PM2.5 & carcinogenic, allergic and irritating effects \\
\hline Microorganisms & $\begin{array}{l}\text { allergic reactions (asthma, runny nose, sneezing, skin rashes), } \\
\text { headaches, pneumonia and bronchitis, carcinogenic }\end{array}$ \\
\hline
\end{tabular}

Source: own elaboration based on [9-11].

Table 2 shows health effects of air pollution on the human body. Occurrence of high concentrations of indoor pollutants is associated with health effects [12-14]. Factors influencing the health of room users have been extensively discussed in the reports of the World Health Organization [15].

According to [13], contaminants that are responsible for the greatest burden of disease are PM2.5 suspended particulates, radon and increased high levels of moisture in the air, which promotes the development of pathogenic microorganisms (Fig. 1).

\section{Burden of disease from poor IAQ by pollutant - EU26 - 2010}

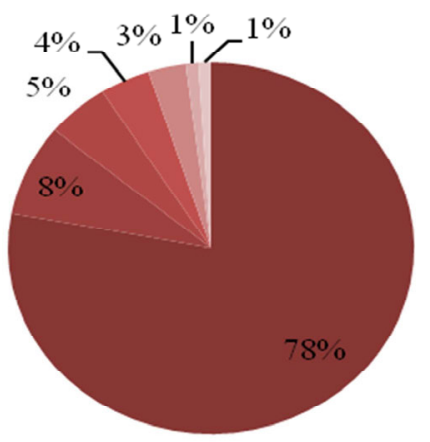

- PM 2.5
Radon
Dampness
-SHS
Bioaerosols
VOC
CO

Fig. 1. Burden of disease from poor IAQ by pollutant - EU26 - 2010. Source: own elaboration based on $[13,16]$. 
It was investigated that PM2.5 contamination is responsible for $78 \%$ of a disease burden. Radon (8\%) and air humidity (5\%) have a much smaller share. Other causes of diseases associated with low air quality are tobacco smoke (4\%), bioaerosols (3\%), volatile organic compounds (VOC) (1\%) and carbon monoxide (CO) (1\%).

\title{
3 Diseases caused by poor air quality - analysis in EU countries
}

The presence of pollutants in the air we breathe is a cause of many diseases, it negatively affects the well-being of people staying in the room. The diagram (Fig. 2) shows the total burden of diseases resulting from poor air quality.

\section{Total burden of disease - EU26 - 2010}

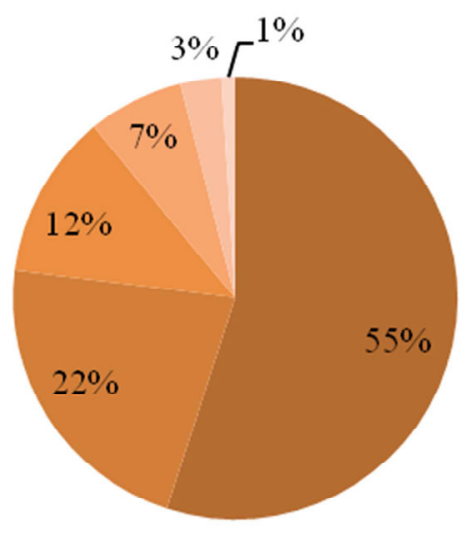

\author{
- Cardiovascular diseases (CV) \\ - Lung cancer \\ Asthma, allergy \\ COPD (chronic obstructive \\ pulmonary disease) \\ U\&L respiratory infections
}

\section{Acute CO toxication}

Fig. 2. Total burden of disease - EU26 - 2010. Source: own elaboration based on $[13,16]$.

While analyzing the occurrence of diseases in 26 European countries, it can be clearly seen that more than half of all cases $(55 \%)$ are cardiovascular diseases. Another disease that burdens the European public in $22 \%$ of cases is lung cancer. Pollutants present in the air usually burden the airways most. Hence, further diseases associated with poor indoor air quality include asthma and allergies (12\%), chronic obstructive pulmonary disease (7\%) and respiratory infections (3\%).

In a moderate European climate, people spend most of the day in closed rooms, at work or at home. Room users are constantly exposed to contamination. It has its effects not only on health but also society, because due to diseases and uncomfortable conditions, life expectancy is shortened. The DALY indicator (Disability Adjusted Life Years) can be used to assess the impact of pollution on health and life expectancy of the society. Table 3 shows the burden of disease in Europe in 2010, the results are shown using the DALY indicator. 
Table 3. Burden of disease in Europe in 2010 by DALY indicator.

\begin{tabular}{|c|c|c|}
\hline \multirow{2}{*}{ Disease } & \multicolumn{2}{|c|}{ Burden of disease } \\
\cline { 2 - 3 } & DALY/million & DALY \\
\hline Cardiovascular diseases (CV) & 2449 & 1184005 \\
\hline Lung cancer & 963 & 465487 \\
\hline Asthma, allergy & 513 & 247903 \\
\hline COPD (chronic obstructive pulmonary disease) & 310 & 149715 \\
\hline U\&L respiratory infections & 124 & 59839 \\
\hline Acute CO toxication & 46 & 22141 \\
\hline Total & $\mathbf{4 4 0 5}$ & $\mathbf{2 1 2 9 0 9 0}$ \\
\hline
\end{tabular}

Source: own elaboration based on $[13,16]$

Analyzing the above list of diseases and the number of lost years of life due to diseases, it can be concluded that air quality has a significant impact on human health. It has been estimated that the most common diseases cause the loss of 2,129,090 years of Europeans' life.

\section{DALY indicator}

Artificial environment in a room and related inadequate air quality cause many diseases, such as asthma, lung diseases, cardiovascular diseases, as well as poor well-being and reduced productivity. The DALY indicator (Disability Adjusted Life Years) means "the loss of life years corrected by disability". It was proposed in 1990 by Murray and Lopez, and is widely used by the World Health Organization to measure the burden of diseases on the population and identify the causes of the diseases [17].

The DALY index is used to measure the disease burden in a studied population. It is an attempt of sorts at a global approach to the problem of illnesses and their impact on the lives of people in society by linking in one formula the length of life and lowering the quality of life due to disability. DALY is used to diagnose the main causes of disease, therefore it is important in the area of health protection. In addition, it has an economic application, because it can be an indication of the allocation of funds in combating the causes of diseases [18].

Exposure to air pollution is associated with incidence of diseases and, as a result, increased mortality. Therefore, The DALY indicator has been proposed as a common measurement tool. General formula is as follows [13, 17]:

$$
D A L Y=Y L L+Y L D
$$

where:

YLL - lost years of life as a result of untimely death,

YLD - years of life spent in disability, illness.

First component of DALY, or YLL (Years of Life Lost) is explained as follows [13, 17, 19]:

$$
Y L L=N \cdot L
$$

where:

$\mathrm{L}$ - standard life expectancy at the age of death in years,

$\mathrm{N}$ - number of deaths. 
However, the YLD (Years Lived With Disability) is calculated as follows [13, 17]:

$$
Y L D=D W \cdot L \cdot N
$$

where:

DW - weight assigned to a given disease,

$\mathrm{L}$ - duration of the disease,

$\mathrm{N}-$ the number of cases of the disease.

YLD component contains the importance of diseases caused by air pollution, thus indirectly determines the impact of air quality on room users health.

\section{Methods of improving the quality of internal air}

Improving indoor air quality can significantly reduce the number of illnesses and improve the comfort of staying in an indoor environment [13].

The first possible method is to optimize the air exchange rate. In this case, the source of pollutant emissions will not be removed, however the concentration of pollution will decrease due to the increase in the number of exchanges [13].

Another way to ensure a better quality of indoor air is through filtration. The filtration can be done using filters in the air handling units. In the outdoor air there are many pollutants that worsen the air condition in rooms. There is a need to use filtration to remove unwanted components of supplied air. In case of indoor air, the quality can be improved using air purifiers.

The last suggested method for improving air quality is to remove sources of pollution in a room. It should be checked whether the equipment and finishing materials are made of materials that meet current hygiene standards [20].

\section{Summary and conclusions}

The quality of indoor air greatly impacts human health and life, especially since we spend most of our day indoors. The low quality of the air we breathe can cause many diseases and significantly reduce the quality of life. The most common contaminants include: carbon monoxide and dioxide, nitrogen oxides, volatile organic compounds, formaldehyde, radon, tobacco smoke, dust, microorganisms. Depending on the concentration and time of contact with contaminants, the most common diseases were observed, mainly cardiovascular diseases, lung cancer as well as asthma and allergies.

For the global approach to the problem of diseases and their impact on society's life, The DALY indicator was proposed as a universal measurement unit. Exposure to air pollution is associated with the incidence of diseases and, as a result, increased mortality. Therefore, The DALY indicator has been proposed as a common measurement tool. DALY is used to diagnose the main causes of disease, therefore it is important in the area of health protection. In addition, it has an economic application, because it can be an indication of the allocation of funds in combating causes of disease.

An important issue is optimization of ventilation and adjusting the system to the needs of the room users. Air quality can be increased by using an increased number of exchanges or by filtering the supplied air. 


\section{References}

1. B. Zabiegała, M. Partyka, J. Namieśnik, Jakość powietrza wewnętrznego - analityka i monitoring, 25 (2003)

2. M. Marć, M. Tobiszewski, B. Zabiegała, M. Guardia, J. Namieśnik, Analyt. Chim. Acta, 853, 116-126 (2015)

3. M. Chludzińska, A. Bogdan, Build. and Environ. 85, 277-286 (2015)

4. B. Zabiegała, Monografie Komitetu Inżynierii Środowiska PAN, 59(2), 303-315 (2009)

5. K. Gładyszewska-Fiedoruk, D.A. Krawczyk, Ener. \& Build. 85, 235-245 (2014)

6. M. Laska, E. Dudkiewicz, E3S Web of Conferences, 22, 00099 (2017)

7. M. Danielak, Chłodn. i Klimatyz. 4(151), 80-84 (2011)

8. J. Müller, D. Skrzyniowska, Zeszyty Naukowe Politechniki Krakowskiej, 4 - Ś, 37-49 (2012)

9. M.B. Nantka, Wentylacja z elementami klimatyzacji (Wydawnictwo Politechniki Śląskiej, Gliwice, 2011)

10. K. Kaiser, Rynek Instalacyjny, 9, 90-96 (2010)

11. A. Cincinelli, T. Martellini, Int. Jour. of Env. Res. And Pub. Heal. 14, 11, 1286 (2017)

12. K. Gładyszewska-Fiedoruk, M. Nieciecki, Energ. Proc. 95, 132-139 (2016)

13. A. Asikainen, P. Carrer, S. Kephalopoulos, E. Oliveira Fernandes, P. Wargocki, O. Hänninen, Environmental Health, 15(Suppl 1), (2016)

14. K. Gładyszewska-Fiedoruk, M. Nieciecki, Energ. Proc. 95, 132-139 (2016)

15. WHO. Public Health, Environmental and Social Determinants of Health (PHE). Burden of disease from Household Air Pollution for 2012 (World Health Organization, Geneva, 2012) http://www.who.int/phe/health_topics/outdoorair/databases

16. A. Asikainen, O. Hänninen, Efficient reduction of indoor exposures. Health benefits from optimizing ventilation, filtration and indoor source controls. Report 2/2013 (National Institute of Health and Welfare, Tampere, 2013) [Access date: 03.04.2018, http://www.julkari.fi/handle/10024/110211]

17. C. J. Murray, Bulletin of the World Health Organization 72(3), 429-45 (1994)

18. A. Ojrzyńska, Studia Ekonomiczne. Zeszyty Naukowe Uniwersytetu Ekonomicznego w Katowicach, 309, 169-178 (2017)

19. O. I.Kolodyazhna, A. Nahorna, Jour. of Ecol. and Heal. 17(4), 191-194 (2013)

20. M. Danielak, Rynek Instal. 3, 30-33 (2012) 